\title{
REAL ESTATE INVESTMENT TRUST DALAM KERANGKA HUKUM PASAR MODAL INDONESIA
}

\author{
Paripurna P. Sugarda ${ }^{*}$
}

\begin{abstract}
The development of property business investment is entering new era. This can be seen with the new instrument, Real Estate investment Trust (REIT), which can be offered to investor in capital market. The emergence of new instrument cause capital needs closely inter-link between property industry and capital market, whereby traditionally, banking industry dominated before. Property market will be more efficient, fair, accountable. It is not only dominated by only some participants/exclusives but also opened investment opportunities for middle or small investor:

A part from that, the tendency of banking industries is very selective to lend fund and high interest, open to grown-up this investment opportunity. Also. Indonesia is judged as one of high potential countries to grow up this property trast because of high property grow-up.

Regard that condition, this paper demonstrates law relation between parties in REIT and how rules of Law of Republic Indonesia Number 8 Year 1995 concerning Capital Market can accommodate the REIT implementation all at once as "law umbrella "in Indonesia Law,
\end{abstract}

Kata kunci : investasi, reksadana, REIT

\section{A. Pendahuluan}

Real Estate Investment Trust (REIT) merupakan hal baru di bisnis properti Indonesia. REIT atau property trust merupakan wahana investasi unik yang gaungnya memang sudah terdengar satu atau dua tahun yang lalu, tetapi pemberitaannya di media hanya baru sebatas wacana.' REIT secara tradisional pada dasarnya adalah "close-end fund" yang diciptakan khusus untuk kepemilikan real estate, aset yang terkait dengan hipotik (mortgage related asset), atau keduanya. ${ }^{2}$

Instrumen investasi ini diciptakan oleh Kongres Amerika Serikat berdasarkan Undang-Undang tentang Real Estate Investment

- Dosen Hukum Dagang Fakultas Hukum Universitas Gidjab Mada Yugyakarta.

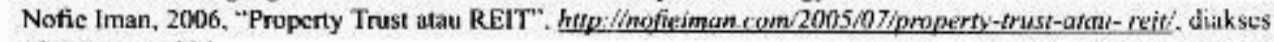
18 Oktober 2006.

2 Chan, ct al, 2003. Real Imvesment Trust-Structure, Perfonnance and Investment Opportunifie. Oxford University Press Inc.. New York, hlm. 5, dikutip olch Renggunis K. Wisuksono, 2005, 'Perspektif Rernl Extate Investment Trast dalam hukum Pasar Modal Indonesia. Thesis Sekolah Pasea Sarjana Magister Hukum Universtas Gadjah Mada, him. 15-18. Sejak diberlakukannya The REIT Modernization Act pada tahun 1999 di Amcrika Scrikat, konsep tradisional REIT sebagai close-end fund mulai mengalami perubahan. REIT sudah diizinkan untuk mengclola asset propertinya sendiri dan menyediakan jasa bagi penyewa properti yang dimslikinya. Sclain itu. scbagaimana reksa dana tertutup. REIT juga diperdagangkan di bursa schingga pemodal dapat memperjualbelikan Unit Penycrtaan atau saham REIT-nya di bursa setiap saat. 
Trust ACt (REIT Act) di tahun 1960. Tujuarnya untuk memberikan kesempatan kepada investor menengah dan kecil berinvestasi di real estate khususnya yang bernilai komersal tinggi (investment grade property), sekaligus menikmati keuntungan seperti yang diperoleh pemilik investment trust. Untuk menarik investor, Kongres menghapuskan pajak pendapatan ditingkat perusahaan (cooperate-level income tax) apabila persyaratan tertentu dipenuhi, seperti bisnis kepemilikan REIT harus mencakup banyak investor dan sebagian besar pendapatan kena pajak harus didistribusikan kembali sebagai dividen kepada investor. ${ }^{3}$

Dalam kurun waktu 40 tahun perkembangannya di Amerika Serikat, kinerja REIT di pasar modal mengalami pasang surut. REIT menjadi alternatif dalam menghimpun dana masyarakat melalui pasar modal pada saat ekonomi mulai pulih dari resesi. Hal ini ditunjukkan dengan meningkatnya jumlah equity REIT dari 25 di tahun 1984 menjadi 176 di tahun 1997 (meningkat 600\%) dan kapatilisasi pasarnya meningkat dari USS 2.3 miliar menjadi USS 127,8 miliar dalam kurun waktu 13 tahun. Berdasarkan data dari riset analisis properti, REIT menyumbang sepertiga $(35,2 \%)$ dari total investasi institusional di sektor properti dan hanya disaingi oleh dana pensiun $(39,4 \%)^{4}$. Perkembangan pusitif tersebut juga terjadi di berbagai belahan negara lain yang juga telah menerapkan skema REIT seperti Jepang, Australia, Hongkong. Singapura. Arab Saudi, Dubay, atau pun Malaysias. Di Indonesia sendiri, setelah dikeluarkannya Peraturan Pemerintah No. 19 Tahun 2005 tentang SMF (Secondary Mortgage Fucility), maka diakhir tahun 2005 BEJ (Bursa Efek Jakarta) berencana menerbitkan Real Estate Investment Trust.

B. Trust, Investment Trust dan Real Estate Investment Trust

Trust merupakan istilah dalam sistem hukum Cammon Law. Dalam pengertian yang fundamental, trust adalah suatu kepercayaan yang diletakkan diatas pundak seseorang yang disebut trustee. Trustee berkewajiban mengelola suatu kekayaan dan kewajiban itu dilaksanakan untuk kepentingan orang lain yang dikenal dengan sebutan beneficiary atau cestui que Trust. Dalam trust hubungan hukum antara dua orang atau lebih atas dasar hak menurut hukum (legal title) untuk kemanfaatan orang lain yang mempunyai kepentingan berdasarkan equity.

Investment Trust dipahami dalam berbagai istilah yang berbeda di beberapa negara. Investment Trust sendiri adalah istilah yang digunakan di Amerika dan Jepang, sedangkan di Inggris digunakan istilah Unit Trust dan Beleggings Fonden di Belanda. Unit Trust sendiri adalah "contractual type of Invesmen Trust" di Jepang. Terkait de-

Ibid.. hlm. 15

+ Schill. Michact H., 1999, "The Impact of the Cupital Markets on Real Fstate Law and Practise", The John Marshall Law School. The John Marshall Law Review. him 5. dixutip olch Rengganis K. Wicaksono, op.cit. hlm. 6

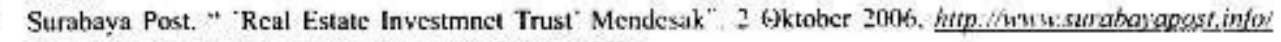
defall.php.'cat $=5$ \& 2 id $=37956$. diakses 10 Oktober 2006.

- F.mmy Pangaribuan Simandjuntak. 1995. "Trust". Penatarın Hukum Perdata Fakultas Hukum UGM. Tidak Dipublikisikan, dikutip okh Rengganis K. Wisaksono, spel hlm. 35-36. 
ngan hal ini, Grayson mengatakan bahwa':

"The theory of Investment Trust is simple. Essentialy, it inwolves the acquisition of cash fund by the trust managers in the purchase of a considerable number of investment which are subject to the lien of the trust's own securities, thereby giving the trust's security holders insurance against loss by mean of diversification of its underlying investment and consequent widwspread of risk":

Mengutip Grayson, istilah investment trust diciptakan di Inggris pada awal tahun 1960-an, pada saat hukum perseroan Inggris Raya dikonsolidasikan ke dalam UndangUndang Perusahaan, sehingga bentuk Trust adalah bukan perusahaan dan lebih bersifat sukarela dengan karakter fiducia ${ }^{8}$.

Beberapa pengertian diberikan terhadap Real Estate Investment Trust (REIT). Definisi dari Dictionary of Finance and Investmnet Terms, Barrons". Pertama, REIT berbentuk perusahaan, biasanya diperdagangkan untuk publik, yang mengelola portofolio real estate untuk menghasilkan keuntungan bagi pemegang saham. Berbentuk seperti perusahaan investasi, REIT melakukan investasi dalam beraneka bentuk real estate seperti shopping center, fasilitas medis, rumah perawatan, gedung perkantoran, komplek apartemen, gudang industri dan hotel. Kechua, real estate adalah sebidang tanah dengan seluruh properti fisik yang berkaitan dengannya, termasuk rumah, pagar, tanaman dan seluruh hak di atas permukaan tanah maupun di bawah permukaan tanah. Aset yang tidak berhubungan langsung dengan tanah dianggap sebagai personal property.

Defenisi dari Black's Law Dictionary ${ }^{\prime \prime}$ adalah sebagai berikut : (1) Real Estate Investment Trust (REIT) adalah sarana keuangan (financial device) dimana investor membeli saham atau Unit Penyertaan di dalam trust yang menginvestasikan dana tersebut dalam banyak real estate. Perusahaan yang melakukan investasi dan melaksanakan pengelolaan portofolio real estate serta mendistribusikan sebagian besar dari pendapatannya kepada pemegang saham. Reksa Dana tertutup (closed-end mutual fund) yang melakukan investasi dalam real estate atau kredit pemilikan properti (mortgage); (2) Real Estate adalah tanah dan segala sesuatu yang secara permanen melekat pada tanah, seperti bangunan, pagar dan segala benda yang melekat pada bangunan, seperti lampu, plumbing dan peralatan pemanas/pendingin ruangan, atau hal lain yang bila tidak merupakan bagian tidak terpisahkan dari bangunan akan masuk dalam kategori personal propertiy. Definisi real estate pada umumnya sinonim dengan real property.

Undang-Undang REIT Amerika Serikat tahun 1960 mendefinisikan REIT sebagai,

Theodoref Grayson, 1928, Imvestment Trast, Their Origin. Development and Operation, Jotun Wiley \& Sons Inc., New York, hlm. 2.

* Ibid, hal I

"Dows, ct al, 1995, Dictionary of Finance and Investment Terms. New York. blm. 460-461. dikutip olch Rengganis K. Wisaksono. op.ct. hlm. 13.

* Black, Henry Campbell. 1991, Black's Law Dictionarv. West Publishing Co.. ST Paul Minnesota, hlm. 12631264, dikutip olch Rengganis K. Wisaksono, op.ct. hlm. 14 
"an unincorporated association with multipte trustee as managers and having transferable shares of beneficial interest " "

Di Jepang REIT didefinisikan sebagai, "kumpulan uang pemodal yang dikumpulkan oleh perusahaan investasi atau manajer investasi dan diinvestasikan ke dalam asset properi, dimana sewa dan hasil penjualan dari asset property tersebut dikembalikan ke pemodal sebagai deviden ${ }^{112}$.

Salah satu keunggulan REIT adalah periakuan khusus perpajakan. Di sejumlah negara, REIT tidak dikenakan pajak penghasilan pada tingkat perusahaan dan pendapatan berupa deviden yang diterima pemodal dikenakan pajak. Namun, demikian untuk menikmati perlakukan khusus tersebut, REIT diharuskan membatasi kegiatan operasional dan investasinya. Persyaratan untuk mempertahankan status bebas pajak tersebut diantaranya, yaitu :13 (1) membayar minimum $90 \%$ dari pendapatan kena pajak kepada pemegang saham setiap tahunnya; (2) memiliki paling tidak 100 pernegang saham dengan tidak kurang dari 5 pemegang saham memiliki lebih dari $50 \%$ saham trust ("5/50 rule"); (3) menjadi investor real estate dan bukan agen perantara (broker); (4) mendapatkan paling tidak $90 \%$ pendapatan kotornya melalui pendapatan sewa dan bunga, keuntungan dari penjualan properti atau saham dari trast lainnya, dan sumber real estate lainnya; (5) mendapatkan minimum $70 \%$ dari pendapatan kotornya melalui kepemilikan real property, keuntungan dari penjualan real property, dan saham dari trust lainnya dan sumber real estate lainnya; dan (6) merniliki paling tidak $75 \%$ dari total asset pada property real estate atau jaminan pinjaman, uang tunai dan sural berharga yang diterbitkan Pemerintah.

Tidak terpenuhinya salah satu persyaratan diatas mengakibatkan status REIT bebas pajak menjadi hilang atau didiskualifikasi sebahagian pendapatannya dari perlakuan bebas pajak pada tingkat korporasi. Namun, Pembatasan tersebut berbeda-beda di setiap negara. Singgapura misalnya, pembatasan tersebut meliputi; (1) harus dimiliki sedikitnya 500 pemodal dengan kewajiban mencatatkan dan memperdagangkan Unit Penyertaan/sahamnya di Bursa Efek; (2) minimal $70 \%$ dananya diinvestasikan di asset property; (3) membagikan $90 \%$ pendapatan kena pajak kepada pemodal pada setiap semester; dan (4) tidak boleh meminjam lebih dari $35 \%$ dari nilai asset propertinya. $^{14}$

Pembatasan ini didasarkan pemikiran bahwa REIT menuakan investasi jangka panjang dan investasi pasif sehingga berbeda dengan sindikasi real estate maupun korporasi real estate. ${ }^{55}$ Pendapatan dari sindikasi maupun korporasi real estate berasal dari kemampuan pengelolaan aset secara aktif melalui pembelian dan penjualan aset secara terus menerus, sedangkan REIT dirancang sebagai instrumen investasi yang

\footnotetext{
Chan, et al, op ct, hlm. 16, dikutip oleh Rengganis Wisaksono, op.ct, hlm. I9

- Basri Pohav dan Andriansyah. "Wacana Real Estate Investment Trust", Sinar Harapan, 31 Agustus 2006.

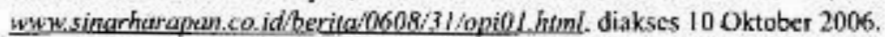

1. Chan. ct al, op.ct. hlm. 16, dikutip oich Rengganis Wisaksono, op.ct. hlm. 19.

14 Basri Pohan dan Adriansyah. loc; $c$ t

4. Ibid'
} 
pasif, dengan larangan untuk secara aktif memperjualbelikan properti atau secara lansung mengelolanya. Oleh karena itu, REIT diharuskan menunjuk perusahaan manajemen properti atau menyewakan propertinya kepada pihak ketiga.

\section{Hubungan Hukum Para Pihak Dalam REIT}

Beranjak dari definisi REIT oleh Barron dan Blacks diatas, maka REIT dapat berupa sebagai a company dan financial device. Pertama, dari definisi Dictionary of Finance and Investment Terms, Barrons, bahwa REIT merupakan perusahaan (company) investasi yang melakukan investasi dan pengelolaan portofolio real estate untuk pemegang sahamnya. Dalam hal ini, REIT merupakan institusi yang memiliki ciri Reksa Dana yang dapat berbentuk perseroan maupun kontraktual (Kontrak Investasi Kolektif). Hanya saja persyaratan terpentingnya adalah $75 \%$ portofolio REIT harus dilakukan dalam bentuk investasi di sektor poperti dan $95 \%$ dari pendapatan bersih tahunan harus dibagikan dalam bentuk deviden. Di Amerika Serikat, REIT yang memenuhi kualifikasi haruslah berbentuk perseroan, trust atau asosiasi (business trust) yang dikenakan pajak sebagai suatu perusahaan. ${ }^{16}$

1. REIT Berbentuk Perseroan

REIT berbentuk Perseroan (PT. REIT) merupakan perusahaan investasi yang melakukan investasi dan pengelolaan portofolio real estate untuk menghasilkan keuntung- an bagi pemegang saham. Sesuai dengan Undang-Undang No. 1 Tahun 1995 tentang Perseroan Terbatas, PT REIT merupakan badan hukum, sehingga aset dan kewajiban PT. REIT adalah terpisah dari aset dan kewajiban pemegang saham maupun Direksi PT. REIT, serta pertanggungjawaban PT. REIT terbatas hanya pada harta kekayaan yang terhimpun dalam perseroan tersebut. ${ }^{17}$

Sebelum menjalankan usahanya, mengikuti ketentuan dalam Pasal 23 Peraturan Pemerintah No. 45 Tahun 1995 tentang Penyelenggaraan Kegiatan di Bidang Pasar Modal, maka PT. REIT berbentuk perseroan harus memperoleh ijin usaha dari Bapepam (Badan Pengawas Pasar Modal) terlebih dahulu. Berdasarkan Keputusan Ketua Bapepam No. Kep-17/PM/1996 tentang Tata cara Permohonan Izin Usaha Reksa Dana berbentuk Perseroan, selain mengisi formulir permohonan Izin Usaha yang bentuk dan isinya sesuai dengan Formulir No. IV.A.1-1, pemohon juga diwajibkan menyertakan dokumen lain seperti akta pendirian perseroan, anggaran dasar Reksa Dana, kontrak pengelolaan Reksa Dana, kontrak penyimpanan kekayaan Reksa Dana antara Reksa Dana dengan Bank Kustodian, dan Penunjukan Profesi Penunjang Pasar Modal, ${ }^{18}$

Pihak-pihak yang terkait dalam REIT Berbentuk Perusahaan adalah Direksi Perusahaan Reksa Dana, Manajer Investasi, Bank Kustodian dan Pemegang Saham, yang hubungannya dapat dilihat dalam struktur di bawah ini's:

16 Garrigan, et at. 1997, Real Estate Imvestment Trust, Structure, Anaivsis und Strategy. Mc-Graw Hill. New York, hlm. 4l, dikutip oleh Rengganis K. Wisaksono, op.ct, hlm. 69.

1- Rengganis K Wisaksonw, op.ct, him. 78.

is Ibid. him. 92

34 Ibid, him. 79 . 


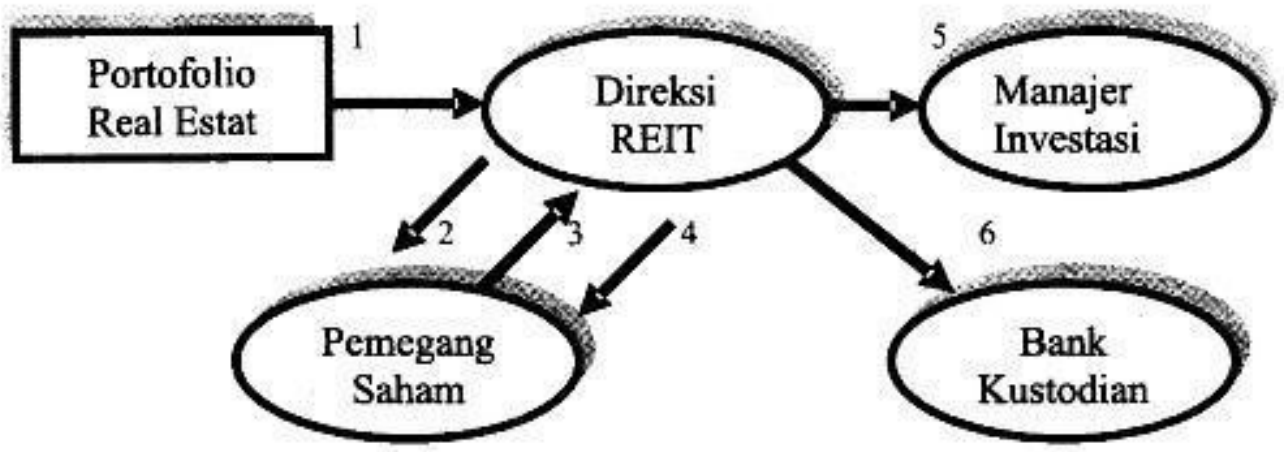

$\mathrm{I}=$ pembelian asset/saham real esate

$2=$ emisi saham

3 = penyertaan modal/pembelian saham

$4=$ dividen

$5=$ kontrak pengelolaan

$6=$ kontrak penyimpanan

Berbeda dengan pengaturan Pasal 82 Undang-Undang No. I Tahun 1995 yang menyatakan bahwa Direksi bertanggungjawab penuh atas pengurusan perseroan untuk kepentingan dan tujuan perseroan, maka pada PT REIT, Direksi lebih berfungsi sebagai wakil dari pemegang saham/pemodal untuk melakukan investasi dan pengelołaan asset real estate untuk kepentingan pemegang saham. Untuk melaksanakan hak-hak pemegang saham, PT REIT akan bertindak untuk dan atas nama para pemegang saham atau sebagai wakil dari pemegang saham yang dianggap telah menguasakan kepada PT REIT melalui- Direksi untuk bertindak atas nama pemegang saham. ${ }^{20}$

Dalam praktek mekanisme transfer kepemilikan portofolio real estate dapat dikatakan bahwa perseroan bertindak untuk pihak ketiga yang akan datang (pemilik saham) dan pihak dalam perjanjian pembelian portofolio real estate tetap PT REIT. Hal ini memang dimungkinkan terjadi dalam praktek pedagangan, yakni dilakukan perjanjian pemberian kuasa untuk hal-hal yang belum terjadi atau masih akan terjadi, seperti misalnya dalam perjanjian kemakelaran. ${ }^{21}$ Artinya, setelah investor membeli saham PT REIT, maka diikatlah investor tersebut dalam suatu perjanjian pemberian kuasa kepada perseroan untuk mewakili kepentingannya atas portofolio real estate. Mekanisme ini dalam hukum Eropa Kontinental dikenal dengan bewindvoerder, Dalam konstruksi di atas, secara yuridis perseroan adalah pemilik (jurisdische eigenaar) dari portofolio real estate, tetapi dari fakta hampir seluruh keuntungan hasil dari kepemilikan asset tersebut sepenuhnya diberikan kepada pemegang saham sebagai deviden. Oleh karena itu, lebih tepat dikatakan bahwa pemilik ckonomisnya (economische eigenaar) adalah pemegang saham/investor.

Jika dilihat dari sistem hukum keperdataan Indonesia yang menganul sistem $\mathrm{Hu}$ -

\footnotetext{
lbid.

2. Ibid, him. 80. Makelar sesuai dengan ketentuan Pasal 62 KUHD (Kitab Undang-Undang Hukum Dagang) pada umurnnya bertindak untuk dan atas nama pemberu kuasa atau prinsipalnya.
} 
kum Eropa Kontinental, PT. REIT menunjukkan adanya karakter dari lembaga fiducia cum amico. Menurut Asser Beekhuis, lembaga fiducia cum amico terjadi bila seseorang menyerahkan kewenangannya kepada pihak lain atau menyerahkan suatu barang kepada pihak lain untuk diurus. Berbeda dengan bentuk fiducia cum creditore, kewenangan diserahkan kepada pihak penerima tetapi kepentingan tetap ada pada pihak pemberi. Dengan perkataan lain, penerima menjalankan kewenangan untuk kepentingan pihak pemberi. ${ }^{22}$

Dalamprakteknya, kedudukan PT. REIT lebih mengarah kepada kedudukan Trustee, sebagaimana dikenal di dalam sistem hukum Aglo Saxon atau Cammon Law. Sebagai Trustee, PT, REIT merupakan badan hukum atau lembaga yang diberi kewenangan memiliki harta yang berupa portofolio real estate yang dipercayakan kepadanya untuk kepentingan pemegang saham. Dalam hal ini, Trustee berkedudukan sebagai legal owner atas kekayaan trust atau trustor. Arti dari konsep Trustee sebagai legal owner adalah sama dengan konsep lembaga fiducia yang berasal dari hukum Romawi dan sekarang dikenal dengan Civil Law.

Trustee sebagai pengelola jika dibandingkan dengan bewindvoerder dalam konsep hukum Belanda, memiliki kesamaan dalam hal mengelola suatu properti untuk kepentingan pihak ketiga (beneficiary). Perbedaanya, kewenangan pengelolaan Trustee didasarkan atas legal title yang diberikan oleh sistem hukum Cammon Law, sedang- kan pada bewindvoerder yang dikenal dalam sistem hukum Civil Law kewenangan pengelolaan itu timbul atas dasar hubungan perwakilan atau kuasa. ${ }^{23}$

\section{REIT Berbentuk Kontrak Investasi Kolektif}

Kontrak Investasi Kolektif (KIK) REIT merupakan kontrak antara Manajer Investasi dan Bank Kustodian dengan pemegang Unit Penyertaan. Hak dan kewajiban pemegang Unit Penyertaan dan Manajer Investasi serta Bank Kustodian diatur di dalam KIK REIT yang dibuat oleh para pihak. Dalam KIK REIT, Manajer Investasi menyatakan akan menguasai dan mengelola properti real estate yang akan menjadi portofolio REIT berbentuk KIK, serta Bank Kustodian untuk melaksanakan penitipan kolektif atas kekayaan berupa portofolio investasi real estate untuk kepentingan dan keuntungan pemegang Unit Penyertaan (beneficial owner). ${ }^{24}$

Dalam KIK REIT tercipta konstruksi Deren Beding atau Janji untuk pihak ketiga. Pihak ketiga ini diartikan oleh Black sebagai "one not a party to an agreement, a transaction, or an action but who may have right therein". Lebih jauh dikenal juga istilah 'third party beneficiary' yang menurut Black adalah "one for whose benefit a promise is made in a contract". Dijelaskan lebih lanjut oleh Black bahwa , "a person not a party to an insurance contract who has legally enforceable right thereunder. A prime requisite to the status of the party beneficiary under a contract is that the parties to the contract

\footnotetext{
fbid, him. 81.

Ibid. him. 82-83

Ibid, him. 85 .
} 
must have intended to benefit the third party. who must be something more than a mere incidental beneficiary". Dengan demikian maka "third-party-beneficiary contract" adalah "contract between two or more parties, the performance of which is intended to benefit directly a third party, thus giving the third party a right to file suit for breach ao contract by either of the original contract parties". ${ }^{25}$

Dalam kaitannya dengan janji untuk pihak ketiga, maka siapa saja yang telah menyatakan kehendak atau kemauannya untuk mempergunakannya. Dengan demikian, janji untuk pihak ketiga sesungguhnya suatu penawaran (offere) yang dilakukan oleh pihak yang meminta untuk diperjanjikan pihak hak (stipulator) kepada pihak ketiga itu. Stipulator tadi tidak dapat menarik kembali perjanjian apabila pihak ketiga telah menyatakan dirinya menerima perjanjian. Pihak dengan siapa stipulator mengadakan perjanjian disebut promisori.

Perjanjian untuk kepentingan pihak ketiga (derden beding) pada dasarnya terbentuk sesuai dengan asas konsensualisme. Namun demikian, karena derden beding merupakan perjanjian tiga pihak, maka hubungan hukum diantara para pihak barulah efektif setelah pihak ketiga mengikatkan diri dalam perjanjian tersebut. Hal ini diwujudkan dengan menyatakan kehendak mengunakan janji stipulator dengan promisor.

Skema Derden Beding dalam Kontrak Investasi Kolektif tersebut dapat digambarkan sebagai berikut ${ }^{26}$.

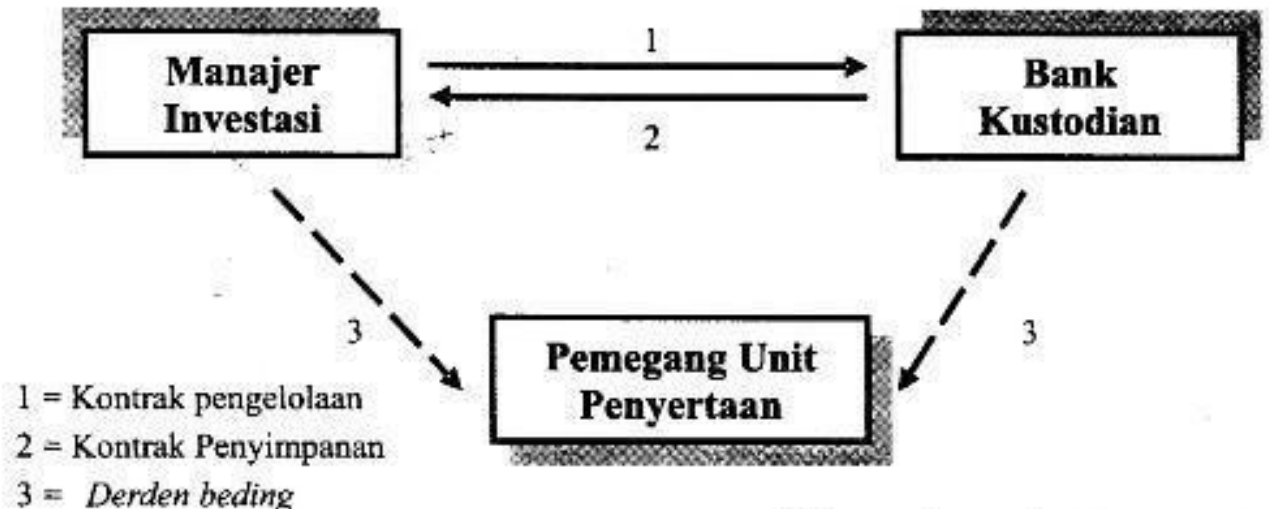

Keterangan:

- Manajer Investasi berjanji kepada Bank Kustodian menyelenggarakan pengelolaan portofolio investasi kolektif untuk kepentingan Pemegang Unit Penyertaan. Dalam hal ini Manajer Investasi merupakan promisor, bank Kustodian adalah stipulator, dan Pemegang Unit Penyertaan sebagai pihak ketiga.

- Bank Kustodian berjanji kepada Manajer Investasi melaksanakan penitipan kolektif untuk kepentingan Pemegang Unit Penyertaan, dengan menerima imbalan jasa berupa pengelolaan portofolio investasi kolektif. Dalam hal

\footnotetext{
:f Black, op.cit, hlm. 1479-1480, dikutip oleh Rengganis K. Wisaksonv, op.ct, hlm. 85-86.

:6 Rengganis K. Wisaksono, op.ct. hlm. 87.
} 
ini Bank Kustodian merupakan promisor, Manajer Investasi adalah stipulator dan Pemegang Unit Penyertaan merupakan pihak ketiga.

Kedua, berdasarkan definisi Black Law Dictionary, REIT merupakan sarana keuangan (financial device) berupa trust. Sebagai financial device investor dapat melakukan pembelian saham trust tersebut (umumnya berbentuk perusahaan atau close-end mutual fund) yang portofolio investasinya adalah dalam bentuk real estate. Sebagai financial device REIT dikelompokkan atas tiga jenis, yaitu :27

a. Equity REIT; dilakukan dengan mengambil posisi ekuitas di dalam real estate dimana pemegang saham/Unit Penyertaan menerima pendapatan dari sewa properti dan capital gain dari penjualan properti. Untuk alasan pajak, invetasi di real estate cenderung dilakukan melalui transfer kepemilikan saham perusahaan properti dan bukan dalam bentuk pembelian asset real estate secara langsung.

b. Mortgage REIT; dilakukan dengan memberikan pinjaman uang kepada developer untuk mengembangkan suatu proyek real estate dan pemegang saham/ unit penyertaan menerima pendapatan dari bunga pinjaman. Bentuk REIT ini mirip dengan konstruksi Efek Bera- gun Aset $^{2 y}$ dimana aset keuangan yang berupa tagihan timbul dari pemberian kredit pinjaman untuk pengembangan di sektor real estate.

c. Hybrid REIT, merupakan kombinasi antara investasi ekuitas dan utang.

\section{Konstruksi Hukum REIT Dalam Undang-Undang Pasar Modal}

Pengaturan mengenai instrumen REIT secara mendetail belum terdapat di Indonesia. Namun demikian, dilihat dari segi konstruksinya, REIT pada dasarnya dapat digolongkan sebagai instrumen Reksa Dana: seperti yang telah diatur melalui UndangUndang No. 8 Tahun 1995 tentang Pasar Modal, dengan ciri bahwa portofolio investasinya dalam bentuk real estate. Reksa Dana sendiri dalam Pasal 1 butir 27 UU Pasar Modal didefinisikan, "wadah yang dipergunakan untuk menghimpun dana dari masyarakat pemodal untuk selanjuntnya diinvestasikan dalam Portofoli Efek oleh Manajer Investasi".

Ketentuan mengenai Reksa Dana diatur dalam Bab IV, Pasal 18-29, UU Pasar Modal. Mengacu pada Reksa Dana sebagaimana dinyatakan dalam Pasal 18 UU Pasar Modal, maka REIT dapat berbentuk Perseroaan atau Kontrak Investasi Kolektif. Untuk Reksa Dana berbentuk Perseroan, sesuai dengan ketentuan pada Pasal 23 Peraturan Pemerintah No. 45 Tahun 1995 tentang Penyeleng-

17 Sbid, hlm. 123.

28 Peraturan Bapepam No IX.K. 1, memberikan defenisi EBA (Efek Beragun Asct), yaitu: adalah cfek yang diterbitkan olch Kontrak Investasi Kolcktif Efck Beragunan Aset yang portofolionya tcrdiri dari aset kcuangan bcrupa tagihan yang timbul dari surat berharga komersial, tagihan kartu kredit, tagihan yang timbul dikcmudian hari (future receivables). pemberian kredit termasuk kredit kepemilikan rumah atau apartemen, efek bersifat huang yang dijamin Pemcrintah, Sarana Peningkatan Kredit (credit enchanment)/Arus kus (cash flow), scrta asct keuangan sctara dan asct kcusngan lain yang berkaitan dengan keuangan terscbut. 
garaan Kegiatan di Bidang Pasar Modal, maka REIT berbentuk perseroan harus memperoleh ijin usaha dari Bapepam terlebih dahulu. Sedangkan Reksa Dana KIK (Kontrak Investasi Kolektif) dalam pengeloaan portofolio efek oleh Manajer Investasi, harus dilakukan berdasarkan kontrak yang dikenal dengan Kontrak Investasi Kolektif.

Penjelasan Pasal 18 ayat (1) huruf (b), menyatakan Kontrak Investasi Kolektif adalah kontrak antara Manajer Investasi dan Bank Kustodian yang mengikat pemegang Unit Penyertaan. Manajer Investasi diberi wewenang untuk mengelola portofolio investasi kolcktif dan Bank Kustodian diberi wewenang untuk melaksanakan penitipan kolektif. Reksa Dana berbentuk KIK menghimpun dana dana dengan menerbitkan Unit Penyertaan kepada masyarakat pemodal dan selanjutnya dana tersebut diinvestasikan pada berbagai jenis efek yang diperdagangkan di Pasar Modal dan Pasar Uang.

Terkait dengan KIK ini, dari ketentuan Pasal 21 ayat (3) jo Pasal 26 ayat (2) dapat disimpulkan bahwa UU Pasar Modal menganggap bahwa Kontrak Investasi Kolektif memuat dua kontrak, yaitu kontrak pengelolaan dan kontrak penyimpanan kekayaan investasi kolektif. Penjelesan Pasal 21 ayat (3) yang bermaksud memberikan deskripsi mengenai 'kontrak penyimpanan' maupun Pasal 26 ayat (2) mengenai 'kontrak penyimpanan', tidak memberikan pengertian kedua kontrak tersebut, melainkan hanya penjelasan mengenai isi kontrak. ${ }^{2 \varphi}$
Penjelasan Pasal 18 ayat (1) huruf a UU Pasar Modal, menyatakan bahwa Reksa Dana berbentuk perseroan adalah emiten yang kegiatan usahanya menghimpun dana dengan menjual saham, dan selanjutnya dana dari penjualan saham tersebut diinvestasikan pada berbagai jenis efek yang diperdagangkan di Pasar Modal dan Pasar Uang. Dalam konteks ini, maka REIT berbentuk perseroan adalah emiten yang kegiatan usahanya menghimpun dana dengan menjual saham, dan selanjutnya dana dari penjualan saham tersebut diinvestasikan pada portofolio real estate, baik melalui pembelian saham maupun aset properti secara langsung.

Dikarenakan bentuknya sebagai perseroan, maka sesuai dengan Undang-Undang No. 1 Tahun 1995, PT REIT adalah suatu badan hukum, sehingga aset dan kewajiban PT REIT adalah terpisah dari aset dan kewajiban pemegang saham maupun Direksi PT REIT, serta pertanggungjawaban PT REIT terbatas hanya pada harta kekayaan yang terhimpun dalam perseroan tersebut. ${ }^{30}$

Sebelum menjalankan usahanya, berdasarkan Pasal 21 ayat (2) jo. Pasal 26 ayat (1) UU Pasar Modal, terlihat bahwa di dalam Reksa Dana berbentuk perseroan bahwa kontrak Pengelolaan Reksa Dana dibuat oleh Direksi dengan Manajer Investasi dan kontrak Penyimpanan kekayaan Reksa Dana dibuat oleh Direksi Reksa Dana dengan Bank Kustodian. Dengan demikian, REIT berbentuk perseroan harus memuat dan melaksanakan kedua kontrak di atas, yang dilakukan oleh Direksi PT REIT dengan Manajer Investasi

29 Ibid, hlm. 100-101

30 Nindyo Pramono, 1997, Sertifikasi Saham PT Go Public dan Huhum Pasar Modal Di Indonesia, PT Citru Aditya Bakti, Bandung. hlm. 24-27. 
dan Bank Kustodian. ${ }^{31}$

Penjelasan Pasal $2 \mathrm{I}$ ayat (2) UU Pasar Modal yang bermaksud memberikan deskripsi mengenai 'kontrak pengelolaan', tidak memberikan pengertian kontrak tersebut, melainkan hanya menjelaskan isi kontrak pengelolaan, yang meliputi: (1) Rencana diversifikasi portofolio di pasar uang dan dipasar modal, (2) Rencana diversifikasi Efek dalam obligasi dan saham, (3) Rencana diversifikasi dalam bidang industri, dan (4) Larangan invesatasi dalam bidang-bidang tertentu. Dalam kontrak pengelolaan REIT berbentuk perseroan perlu juga ditambahkan persyaratan mengenai rencana alokasi portofolio real estate, bentuk investasi yang dilakukan apakah ekuisitas atau pinjaman atau hybrid, justifikasi pemilihan jenis properti, profil pendapatan dan jenis risiko yang ada serta tingkat ekspektasi yield. ${ }^{32}$

Penjelasan Pasal 26 ayat (1) mengenai 'kontrak penyimpanan' memuat penjelasan mengenai tugas dan kewajiban Direksi Reksa Dana, bahwa Direksi Reksa Dana dapat bertindak mengawasi pelaksanaan pengelolaan Reksa Dana termasuk penyimpanan kekayaan Reksa Dana. Oleh karena itu, Direksi PT REIT wajib membuat Kontrak Penyimpanan Kekayaan Reksa Dana dengan Bank Kustodian. ${ }^{33}$ Pedoman mengenai isi kontrak tersebut diatur lebih lanjut dalam Keputusan Ketua Bapepam No. KEP-20/PM/1996 tentang Pedoman Kontrak Pengelolaan Reksa Dana Berbentuk Perseroan dan Keputusan Bapepam No. KEP-21/PM/1996 tentang
Pedoman Kontrak Penyimpanan Kekayaan Reksa Dana Berbentuk Perseroan.

Dalam perjanjian Reksa Dana berbentuk perseroan, direksi Reksa Dana dapat memutuskan perjanjian dengan Manajer Investasi maupun Bank Kustodian dengan syarat-syarat tertentu. Selain itu, sesuai dengan Peraturan Bapepam No. IV.A.3 mengenai Pedornan Pengelolaan Reksa Dana Berbentuk Perseroan, dinyatakan bahwa dalam hal Reksa Dana tersebut dibubarkan, maka biaya Konsultan Hukum, Akuntan dan beban lain kepada pihak ketiga yang merupakan kewajiban Reksa Dana menjadi tanggung jawab dan wajib dibayar Manajer Investasi kepada pihak-pihak yang bersangkutan. Ketentuan ini kiranya juga dapat diterapkan pada REIT yang berbentuk Perseroan. ${ }^{34}$

Mengacu kepada Peraturan Bapepam No. IV.A.3 Poin 1 butir (a), Kontrak Pengelolaan Reksa Dana yang dibuat oleh Direksi Reksa Dana dengan Manajer Investasi Direksi PT. REIT wajib menugaskan Manajer Investasi yang telah memperoleh ijin usaha untuk melakukan pengelolaan investasi PT. REIT dan melaksanakan kegiatan lainnya yang diperlukan serta menunjang fungsinya sebagai Manajer Investasi berdasarkan suatu Kontrak Pengelolaan. ${ }^{35}$

Selanjutnya mengacu pada butir 1 huruf c, Kontrak Pengelolaan PT. REIT wajib terlebih dahulu memperoleh persetujuan dari sebagian besar Direksi PT. REIT tersebut, serta pada huruf $d$ dan $f$ tegas dinyatakan bahwa semua pengalihan dan rencana pe-

\footnotetext{
Renggunis K. Wisaksono, 2005, loc cit.

Ibid, h]m. 128.

Ibid; hlm. 129.

Ibid, hlm. 131

16rid.
} 
mutusan kontrak pengelolaan wajib memperoleh persetujuan dari sebagian direktur. Hal ini kembali ditegaskan dalam Peraturan Bapepam No. IV.A.4 butir 16 yang menyatakan bahwa Kontrak Pengeloaan Reksa Dana, Kontrak Penyimpanan Kekayaan atau Kontrak pengunaan jasa akuntan hanya dapat dibuat, diperpanjang atau dialihkan berdasarkan persetujuan sebagian besar direktur utama. ${ }^{36}$

Sesuai Peraturan Bapepam No. IV.A.5 mengenai Kontrak Penyimpanan Kekayaan Reksa Dana berbentuk Perseroan, antara Direksi PT. REIT dengan Bank Kustodian, memuat kewajiban Bank Kustodian untuk memberikan jasa penitipan efek dan harta lain yang berkaitan dengan efek serta jasa lainnya yang terutama merupakan investasi real estate, termasuk menerima pendapatan sewa, deviden, bunga, hak-hak lain dan menyelesaikan transaksi efek atau aset. Bank Kustodian berkewajiban untuk membuat dan menyampaikan laporan kepada Manajer Investasi, PT REIT dan Bapepam. Namun demikian, dalam peraturan ini tidak dijelaskan apakah kontrak penyimpanan ini wajib dibuat secara notariil. ${ }^{\text {" }}$

Dari uraian di atas terlihat adanya Direksi PT. REIT melalui kontrak yang dibuat dengan Manajer Investasi dan Bank Kustodian, mewakili kepentingan para pemegang saham untuk terlaksananya pengelolaan investasi yang memberikan keuntungan semaksimal mungkin serta penyimpanan kekayaan yang diadministrasikan secara baik. ${ }^{\mathrm{K}}$
Hubungan hukum antara Pemegang Unit Penyertaan dengan Manajer Investasi tidak dijelaskan secara eksplisit dalam UU Pasar Modal, namun dalam Pasal 27 ayat (1) dinyatakan bahwa, "Manajer Investasi wajib dengan itikad baik dan penuh tanggungjawab menjalankan tugas sebaik mungkin semata-mata untuk kepentingan Reksa Dana". Kata-kata "untuk kepentingan Reksa Dana" dalam konteks REIT KIK ini mencerminkan adanya makna Manajer Investasi melakukan fungsi pengelolaan untuk kepentingan Pemegang Unit Penyertaan. Penjelasan dari pasal tersebut menjelaskan bahwa, "Mengingat semua dana yang dikeIola oleh Manajer Investasi adalah dana masyarakat, perlu adanya pengamanan maksimal dengan mewajibkan Manajer Investasi untuk melaksanakan tugasnya sebaik mungkin untuk kepentingan Reksa Dana"."

"Dana masyarakat" dalam konteks REIT KIK ini adalah dana milik Pemegang Unit Penyertaan. Tampak di sini adanya unsur perwakilan tidak langsung, yakni Pemegang Unit Penyertaan sebagai orang yang diwakili dan Manajer Investasi sebagai orang yang mewakili dalam pengelolaan efek/asset dalam portofolio REIT. Dikatakan "tidak langsung" karena Manajer Investasi membeli dan menjual portofolio investasi real estate milik Pemegang Unit Penyertaan secara kolektif, tetapi bukan atas nama Pemegang Unit Penyertaan melainkan atas nama Bank Kustodian. ${ }^{41 !}$

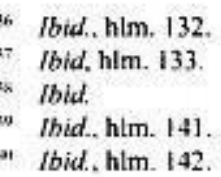


Menurut Pasal 1 butir 29 UU Pasar Modal, Pemegang Unit Penyertaan mempunyai kepentingan dalam portofolio Kontrak Investasi Kolektif. Besarnya kepentingan tersebut tercermin dari jumlah lembar Unit Penyertaan yang dimiliki. Untuk memahami arti investasi kolektif dalam konstek Unit Penyertaan dapat dilihat dari Pasal 56 ayat (3) UU Pasar Modal yang menyatakan bahwa :"1 "Apabila efek dalam penitipan kolektif pada Bank Kustodian merupakan bagian dari Portofolio Efek dari suatu Kontrak Investasi Kolektif dan tidak termasuk dalam penitipan kolektif pada Lembaga Penyimpanan dan Penyelesaian, maka efek tersebut dicatat dalam buku daftar pemegang Efek Emiten atas nama Bank Kustodian untuk kepentingan pemilik Unit Penyertaan dari Kontrak Invesatisi Kolektif tersebut".

Kata-kata "atas nama Bank Kustodian untuk kepentingan pemilik Unit Penyertaan" tersebut memastikan bahwa keseluruhan Pemegang Unit Penyertaan adalah "perniliki kolektif' dari efek/aset dalam portofolio investasi REIT, serta perbuatan Bank Kustodian dalam mengadministrasikan efek/ aset tersebut adalah untuk kepentingan Pemegang Unit Penyertaan. Di sini sekali lagi terlihat adanya penerimaan konsep perwakilan tidak langsung yang melingkupi hubungan hukum antara Pemegang Unit Penyertaan sebagai pihak yang diwakili dengan Bank Kustodian sebagai pihak yang mewakili, dalam pengadministrasian efekefek yang terdapat pada portofolio REIT. ${ }^{42}$ Hal ini tampak lebih jelas pada Penjelesan dari Pasal 56 ayat (3) tersebut, yang menyatakan bahwa": "Ketentuan ini dimaksudkan bahwa berdasarkan Undang-undang ini keseluruhan pemilik Unit Penyertaan Reksa Dana berbentuk Kontrak Investasi Kolektif adalah pihak yang mewakili atau berhak atas Efek yang termasuk dalam portofolio Reksa Dana dimaksud. Kepemilikan tersebut diwakili oleh Bank Kustodian dengan mencatatkan nama Bank Kustodian tersebut dalam buku daftar pemegang Efek Emiten. Bank Kustodian dalam hal ini semata-mata bertindak selaku wakil dari keseluruhan pemilik Unit Penyertaan Reksa Dana dimaksud". Dari penjelasan tersebut tanpak adanya hubungan perwakilan antara pemegang Unit Penyertaan dan Bank Kustodian melalui kata-kata "bertindak selaku wakil" dari keseluruhan pemilik Unit Penyertaan REIT KIK.

Jika dlihat dari bentuk invesatsi REIT ke dalam efek baik dalam bentuk saham maupun pinjaman di sektor real estate terlihat bahwa UU Pasar Modal mengenai Reksa Dana tidak cukup mengakomodasi bentuk investasi tersebut, karena adanya persyaratan bahwa efek tersebut diperdagangkan di Pasar Modal dan Pasar Uang. Selain itu, apabila REIT melakukan pembelian aset properti secara langsung, hal ini juga tidak diakomodasi dalam peraturan mengenai Reksa Dana dalam UU Pasar Modal.*

Selain itu, Pasal 24 Undang-Undang Pasar Modal melakukan pembatasan bahwa Reksa Dana dilarang menerima dan atau memberikan pinjaman secara langsung dan

s) Ibid

4. Ibid., bim. 143 .

13 Ibid.

4 Jbid, him 124. 
Reksa Dana juga dilarang membeli saham atau Unit Penyertaan Reksa Dana lainnya. Hal ini tentunya membatasi ruang gerak REIT, yaitu 'mortgage REIT' yang seharusnya dapat digunakan sebagai instrumen investasi dengan melakukan pembelian pinjaman secara langsung kepada perusahaan pengembang (developer). Dalam pengaturan REIT di Amerika juga diperbolehkan REIT melakukan pembelian saham dari reksa dana (trust) lainnya di sektor real estate. ${ }^{4}$

\section{E. Penutup}

Hubungan hukum para pihak dalam REIT dapat dilihat dalam dua bentuk. Perta$m a$, Perseroan. Hubungan para pihak (Direksi REIT, Manajer Investasi, Bank Kustodian, dan Pemegang Saham) terikat ketentuan dalam Undang-Undang No. 1 Tahun 1995 tentang Perseroan Terbatas. REIT merupakan badan hukum yang modalnya terbagi atas saham yang dimiliki para investor dan dinvestasikan oleh Manajer Investasi dalam portofolio real estate. Hutang dan kewajiban PT. REIT terpisah sari hutang dan kewajiban pernegang saham maupun Direksi PT. REIT. PT. REIT merupakan pemilik (jurisdische eigenaar) atas portofolio real esate, namun pernegang saham/investor merupakan pemilik ekonomis (economische eigenaar). Kedua, Kontrak Investasi Kolektif (KIK). Hak dan kewajiban para pihak (pemegang Unit Penyertaan, Manajer Investasi, dan Bank Kustodian) diatur dalam KIK. Manajer Investasi menyatakan akan menguasai dan mengelola properti real estate yang akan menjadi portofolio REIT, serta Bank Kustodian melakukan penitipn kolektif atas kekayaan berupa portofolio investasi untuk kepentingan pemegang Unit Penyertaan.

REIT berbentuk Perseroan (Company) dan REIT berbentuk KIK (Business Trust) dimungkinkan keberadaanya dalam sistem hukum Indonesia, tetapi perlu menjadi perhatian dalam struktur hukum Reksa Dana sebagaimana diatur dalam UU Pasar Modal bahwa portofolio investasi Reksa Dana harus berupa efek yang diperdagangkan di Pasar Modal dan Pasar Uang, sedangkan portofolio investasi REIT adalah berupa asset real estate atau efek (baik yang bersifat ekuitas atau piutang) yang berkaitan dengan real estate yang tidak diperdagangkan di Pasar Modal dan Pasar Uang. REIT berbentuk Perseroan dapat dimungkinkan keberadaanya di Indonesia berdasarkan Undang-Undang No. 1 Tahun 1995, yakni Perseroan dengan asset atau ekuitas berupa real estate yang membentuk portofolio investasi untuk mendapatkan keuntungan semaksimal mungkin bagi pemegang saham. Jika dikehendaki suatu REIT berbentuk Perseroan yang sesuai dengan struktur hukum Reksa Dana, maka dapat dilakukan pembelian saham atas PT. REIT yang telah terdaftar dan diperdagangkan di Pasar Modal olch Reksa Dana berbentuk perseroan atau KIK, sehingga memenuhi persyaratan portofolio investasi Reksa Dana berupa efek yang diperdagangkan di Pasar Modal. Namun demikian, hal ini masih harus dilihat lagi dari aspek perpajakannya. 


\section{DAFTAR PUSTAKA}

A. Buku.

Black, Henry Campbell, 1991. Black's Law Dictionary, West Publishing Co., ST Paul Minnesota.

Chan, Su Han, Erickson, John, Wang, Ko, Real Esate Investment Trust-Structure, Performance and Investment $O p$ portunities, Oxford University Press Inc., New York.

Down, John, Goodman, Jordan Elliot, 1995. Dictionary of Fianace and Investment Terms, New York.

Garrigan, Richard T., Parsons, John F.C., 1997, Real Estate Investment Trust. Structure, Analysis and Strategy, McGraw Hill, New York.

Grayson, TheodoreJ., 1928, Investment Trust, Their Origin, Development and Operation, John Wiley \& Sons Inc., New York, hal.2

Pramono, Nindya, 1997, Sertifikasi Saham PT Go Public dan Hukum Pasar Modal Di Indonesia, PT Citra Aditya Bakti, Bandung

Simanjuntak, Emmy Pangaribuan. 1995, Trust, Yogyakarta, Penataran Hukum Perdata: Fakultas Hukum UGM, Tidak Dipublikasikan.

Schill, Michael H., 1999, "Paper Symposium: The Impact of the Capital markets on Real Estate Law and Practise", The John Marshall Law School, The John Marshall Law Review.

\section{B. Artikel dan Surat Kabar}

Surabaya Post, “ 'Real Estate Investmnet Trust' Mendesak", 2 Oktober 2006, http://www.surabayapost info/detail.

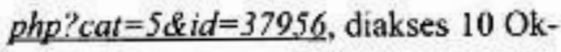
tober 2006.

Basri Pohan dan Andriansyah, "Wacana Real Estate Investment Trust". Sinar Harapan,31 Agustus 2006, wwwsinarharapan.co,id/berita/0608/31/opi01. html, diakses 10 Oktober 2006

Nofie Iman, 2006, "Property Trust atau REIT", http://nofieiman.com/2005/07/ property-trust-ataw- reitl, diakses 18 Oktober 2006.

C. Peraturan Perundang-undangan

Undang-Undang No. 8 Tahun 1995 tentang Pasar Modal.

Undang-Undang No. 1 Tahun 1995 tentang Perseroan Terbatas.

Peraturan Pemerintah No. 45 tahun 1995 tentang Penyelenggaraan Kegiatan di Bidang Pasar Modal.

Peraturan Pemerintah No. 19 Tahun 2005 tentang Secondary Mortgage Facilit.

Keputusan Ketua Bapepam No. Kep-17/ PM/1996 tentang Tata Cara Permohonan Izin Usaha Reksa Dana.

Keputusan Ketua Bapepam No. KEP-20/ PM/1996 tentang Pedoman Kontrak Pengelolaan Reksa Dana Berbentuk Perseroan.

Keputusan Bapepam No. KEP-21/PM/1996 tentang Pedoman Kontrak Penyimpanan Kekayaan Reksa Dana Berbentuk Kontrak Investasi Kolektif. Mengenai Pedoman Kontrak Pengelolaan Reksa Dana Berbentuk Perseroan (Keputusan Ketua Bapepam KEP-20/PM/1996) dan (Keputusan Bapepam KEP-21/ PM/1996). 